\title{
Antibacterial Efficacy of Catharanthus roseus Leaf Extract on Sewage Water
}

\author{
Ashutosh Kumar Verma and Neelam Gautam*
}

Botanical Survey of India, Central Regional Centre, 10- Chatham Line Allahabad, 211002, India

*Corresponding author

\section{Keywords \\ Sewage, \\ Catharanthus \\ roseus, Plant \\ extract, \\ Antimicrobial. \\ Article Info \\ Accepted: \\ 04 April 2017 \\ Available Online: \\ 10 May 2017}

\section{A B S T R A C T}

\section{Introduction}

Sewage entering into the rivers is a major threat and possesses detrimental effects on human health. The silt, debris and other depositions present in the sewage results into rapid rise of the bacterial population in polluted fresh water system. Thus, increasing discharge of untreated sewage water in rivers has lead severe pollution and threat to living beings. According to a survey Indian rivers are heavily polluted and about 29,000 million litres per day of sewage require treatment (Central Pollution Control Board). Its criticality has attracted many researchers to get alternative and cost effective methods for treatment of sewage prior to exposure in any fresh water system.

India is one of the richest in plant diversity and the ethos to use plant products in innumerable ways for human life is deep rooted. Ethnomedicinal plants produces a large number of chemical compounds such as alkaloids, flavonoids, terpenoids, etc. which render them antibacterial potentiality. Use of plant products against microbes is not new to science and the antimicrobial properties of plants have received attention from researchers for extensive exploration of application of plant extracts. Also the tendency of microbes to acquire resistivity against developed chemicals recall for exploration of newer drugs. Earlier several researchers (Bhalodia and Shukla, 2011; Sathiya et al., 2008; Sheyin et al., 2010; Virmani et al., 1978) have shown antimicrobial potentiality of plants extract in their in vitro studies which indicates potentiality of plant products to control 
microbial population in any system including sewage. Sharmila et al., (2013) have shown that Moringa leaf extract are effective in clarification and reduction of hardness of polluted water. Perusal of these findings depicts that treatment through plant extract seems more reliable as besides bearing effective antimicrobial property, they are safe for environment, economical and easily available alternative. The present study was documented to assess the antimicrobial property of leaf extract of Catharanthus roseus (L.) Don on growth of bacterial population on sewage water from 3 different sources. In the present context $C$. roseus has been selected because of its high effectiveness and is well known for its therapeutic uses as it consist of innumerable chemical compounds chief among them are vinblastine and vincristine with effective antibacterial property.

\section{Materials and Methods}

For present study, sewage samples were collected from three different sites (viz. Haider canal, Lucknow University Campus and Alambagh region) of Lucknow, Uttar Pradesh, India. All samples were filtered with muslin cloth to remove out solid wastes. Later on each sample were divided into two lots $(100 \mathrm{ml})$ one lot treated as control while remaining lot used for treatment. For preparation of the leaf extract healthy leaves of $C$. roseus were collected from the garden of Department of Botany, Lucknow University, India. The leaves were thoroughly washed with distilled water, chopped and dried in an oven at $30^{\circ} \mathrm{C}$ for 5 days. The leaves were homogenized to a fine powder with the help of mechanical grinder. The crude aqueous extract was prepared by heating slowly $10 \mathrm{~g}$ leaf powder with $100 \mathrm{ml}$ distilled water for $6 \mathrm{~h}$ and the extract was filtered through a muslin cloth. The extract was concentrated to one fifth of the total volume.

At initial stage of experiment count of gram positive and gram negative bacteria were made by utilizing Gram staining technique for all sewage samples. Later on, one lot of each sample impregnated with $10 \mathrm{ml}$ of $C$. roseus leaf extract and bacterial count for each sample were made after 7 days of treatment by similar methodology including count in control samples.

\section{Results and Discussion}

The results of present study indicate that, all the three samples contained varying degree of bacterial pollution and sewage of university campus suffering from heavy bacterial pollution. That was probably due to conditional variation present at mentioned site such as in Haider canal several industrial effluents are exposed which checked bacterial population at some extent. It was examined that all three sewage samples contained higher load of Gram (+) than Gram (-) bacteria. Observations of $7^{\text {th }}$ day revealed that population size of both type of bacteria increased in untreated sets (control) and declined in treated sets (Table 1) that reflects antibacterial potential of $C$. roseus leaf extracts in in-vivo conditions and showed inconsonance with the findings of earlier workers under in-vitro culture condition (Sathiya et al., 2008; Verma et al, 2010). The alkaloids and other secondary metabolites present in the extract were able to reduce the bacterial population. The elongation of treatment period resulted in declined bacterial population as compared to control. This supports the antibacterial efficacy of $C$. roseus extract in sewage samples. 
Table.1 Effect of $10 \%$ leaf extract of C. roseus on bacterial growth in sewage water samples

\begin{tabular}{|c|c|c|c|c|c|c|}
\hline \multirow{3}{*}{$\begin{array}{c}\text { Sewage } \\
\text { sample site }\end{array}$} & \multirow{2}{*}{\multicolumn{2}{|c|}{$\begin{array}{l}\text { Bacteria/ microscopic field } \\
\text { (Average } \pm \text { SE) } \\
\text { Day-1 }\end{array}$}} & \multicolumn{4}{|c|}{$\begin{array}{c}\text { Bacterial count/ microscopic field (Average } \pm \text { SE) } \\
\text { (\% increase/decrease in bacterial count over control) } \\
\text { Day-7 }\end{array}$} \\
\hline & & & \multicolumn{2}{|c|}{ In Control samples } & \multicolumn{2}{|c|}{ In treated samples } \\
\hline & Gram + & Gram - & Gram + & Gram - & Gram + & Gram - \\
\hline Haide & $334.67 \pm 16.96$ & $186.67 \pm 02.08$ & $\begin{array}{c}553.33 \pm 08.81 \\
(+65 \%)\end{array}$ & $\begin{array}{c}381.66 \pm 15.81 \\
(+104 \%)\end{array}$ & $\begin{array}{c}182.00 \pm 11.54 \\
(-45 \%)\end{array}$ & $\begin{array}{c}153.33 \pm 10.03 \\
(-17 \%)\end{array}$ \\
\hline $\begin{array}{l}\text { University } \\
\text { Campus }\end{array}$ & $480.00 \pm 11.26$ & $225.00 \pm 14.24$ & $\begin{array}{c}754.33 \pm 16.33 \\
(+57 \%)\end{array}$ & $\begin{array}{c}490.67 \pm 09.66 \\
(+118 \%)\end{array}$ & $\begin{array}{c}243.33 \pm 16.67 \\
(-49 \%)\end{array}$ & $\begin{array}{c}175.00 \pm 08.81 \\
(-22 \%)\end{array}$ \\
\hline Alambagh & $420.67 \pm 03.01$ & $220.00 \pm 07.00$ & $\begin{array}{c}554.67 \pm 08.32 \\
(+31 \%)\end{array}$ & $\begin{array}{c}347.00 \pm 03.51 \\
(+77 \%)\end{array}$ & $\begin{array}{c}216.33 \pm 06.67 \\
(-48 \%)\end{array}$ & $\begin{array}{c}146.67 \pm 04.41 \\
(-33 \%)\end{array}$ \\
\hline
\end{tabular}

The sewage water is a major carrier of numerous microbial diseases and this has been frequently used for agricultural purposes. In view of application of sewage water for irrigation it is utmost requirement to extend this finding or more refined findings of future research work on same plant in field for treatment of sewage water so that it can be reused under controlled condition. Moreover, this natural and traditional system of exploration of properties of plant products may pave way to modern technology with long term application (Prasuna and Chandel, 2015).

In conclusion, this survey reflects the practical situation and may serve as the baseline to facilitate effective measures in direction of sewage treatment. Big projects were not successful in Indian scenario due to certain conflicts and cost factors. So, according to community structure of the set up it would be more consistent to put low cost small treatment methods like use of natural products rather than large sewage treatment plant. It also suggests a promising technology of treatment of sewage water in an economic way and without compromising public health.

\section{Acknowledgment}

Authors of manuscript are grateful to Head Department of Botany, University of
Lucknow, India, for providing all necessary facilities and support for executing the experiments.

\section{References}

Bhalodia, N.R., and Shukla, V.J. 2011. Antibacterial and antifungal activities from leaf extracts of Cassia fistula: An ethnomedicinal plant. J. Adv. Pharma. Tech. and Res., 2(2): 104-109.

Prasuna, M.L., and Chandel, U. 2015. Studies of antibacterial activities of leaf extract of selected ethno-medicinal plants. IOSR J. Environ. Sci. Toxicol. Food Tech., 1: 65-66.

Sathiya, S., Karthikeyan, B., Jaleel, A.B., Azooz, M.M., and Iqbal, M. 2008. Antibiogram of Catharanthus rosseus extracts. Global J. Mol. Sci., 3: 1-7.

Sharmila, S., Jeyanthi, R.L. and Saduzzaman, Md. 2013. Effect of plant extracts on the treatment of paint industry effluent. Int. J. Pharm. Bio. Sci., 4(3): 678 - 686.

Sharmila, S., Jeyanthi, R.L., and Saduzzaman, Md. 2013. Domestic waste water treatment using leaf extract of Moringa oleifera. Res. J. Pharma. BioChem. Sci., 4(2): 833-839.

Sheyin, Z., Maimako, J., Shindang, J., Essien, C.U., Bigwan, E.I., and Ede, F.R. 2015. Antimicrobial activity of Albizia 
lebbeck leaf extract on some medically important bacteria. Int. J. Curr. Microbiol. App. Sci., 4(9): 473-477.

Verma, A.K., and Singh, R.R. 2010. Induced dwarf mutant in Catharanthus roseus with enhanced antibacterial activity.
Ind. J. Pharma. Sci., 72(5): 655-657.

Virmani, O.P., Srivastava, G.N., and Singh, P. 1978. Catharanthus roseus: The tropical periwinkle. Ind. Drugs L., (15): 231-252.

\section{How to cite this article:}

Ashutosh Kumar Verma and Neelam Gautam. 2017. Antibacterial Efficacy of Catharanthus roseus Leaf Extract on Sewage Water. Int.J.Curr.Microbiol.App.Sci. 6(5): 238-241. doi: http://dx.doi.org/10.20546/ijcmas.2017.605.027 